\title{
The Intersectionality between Gender and Generation: Millennial Women's Leadership in Dr. PJGMRMC, Cabanatuan City
}

\author{
Camille Anne Bonafe \\ Dr Paulino J Garcia Memorial Research and Medical Center, Philippines
}

Rosemarie Casimiro

Nueva Ecija University of Science and Technology, Philippines

Received: April 3, 2019 Accepted: May 16, 2019 Online published: May 28, 2019

doi:10.5296/jpag.v9i2.14610

URL: https://doi.org/10.5296/jpag.v9i2.14610

\begin{abstract}
The study explores the leadership style of millennial women managers, and their means of defying gender stereotyping and building rapport with their subordinates in the workplace. With the use of qualitative method and intersectionality as framework, the study promotes understanding of the standpoint of millennial women leaders about leadership and all the struggles and challenges in their workplace, fastened onto the notion of leadership as something that subsists at the intersection of the spark and values. Four millennial women managers from the four different divisions of Dr. Paulino J Garcia Memorial Research and Medical Center (Dr. PJGMRMC), a tertiary government hospital in Cabanatuan City in the Philippines namely; Nursing, Medical, Hospital Operation Patient Support Services, and Finance were selected using purposive sampling technique with the following criteria: a) Woman, b) Filipino Millenial (born between year 1981 to 1996), c) With permanent position, and d) Holder of a supervisory/managerial position. One-on-one interviews were conducted with the millennial women managers. Using open-ended questions, participants were asked about their views on leadership, management of staff, experiences in handling conflicts in the workplace, their means of building rapport with the staff and how they defy the gender stereotyping in the workplace to achieve the organizational goals. Participant observation was also employed to have an in-depth and detailed understanding of the situation. Each theme that emerged during the data collection and analysis is presented and supported by existing literatures and the actual data gathered.
\end{abstract}

Keywords: modern-day leaders, gender, intersectionality, women empowerment 


\section{Introduction}

Millennials are those reaching young adulthood in the early $21^{\text {st }}$ century or those born between 1981 and 1996 (Oxford Dictionary, 2016; Pew Research Center, 2010). Based on the 2016 Census of Population (Philippine Statistics Authority (PSA), 2016), about three fourths $(3 / 4)$ of the people living in the Philippines is comprised of millennials. On the other hand, based on the Labor Force Survey conducted on October 15, 2016 by PSA, forty two million Filipinos aged 15 to 34 are actually part of the country's labor force. Statistically, that is four in every nine millennials and $37.4 \%$ of said figure are comprised of women.

At this present time of globalization, Millennials are gaining positions as leaders in the workforce. Attached to their positions is the authority to delegate tasks and oversee organization's performance (Myers and Sadaghiani, 2010). Although young in terms of age and experience, young professionals nowadays are given opportunity for leadership positions since the selection of employees in many organizations are now based on merit-based systems rather than the seniority-based systems (Phelan and Lin, 2000). The Millennials' knowledge of technology, multi-tasking skills, flexibility to changes, and open-mindedness make them ahead of the other generations (Venter, 2017).

In spite their advantage in terms of modern-day skills, there is still concerns about the Millennials' predispositions and communication orientations especially when dealing with the older Boomers and Gen X associates (Myers and Sadaghiani, 2010). Also, discussions have been raised as to their ability to lead and create functional work relationship and enhance organizational performance (McGuire et al., 2007).

Employees are the greatest assets of every organization (Gabčanová, 2011). Nonetheless, it is the leaders who have the greatest responsibility in making their subordinates feel motivated. (Thomson, 1998).Their leadership skills therefore are essential towards the attainment of the goals of their respective organizations. (Yukl, 1998). They act as the captain of the ship that sails the organization to where it wants to go, be it success or failure.

The Millennials nowadays, especially the women are likewise redefining leadership at work regardless of some gender inequality and leadership stereotyping issues (Sandberg, 2013). It is also positive to note that there exists worldwide initiative to ensure gender equality in the workplace and in the society in general. In fact in 2016, Mlambo-Ngcuka, the United Nation's Women's Executive Director, expressed in her speech that,

"UN has a single focus; to achieve worldwide gender equality and the empowerment of women and girls by 2030. This is our mission, uniting us all behind a common purpose. For the first time ever we have invited men and boys around the world to come with us in this journey. By taking an inclusive approach and working together for equality, we can accelerate progress towards its achievement..."

To foster effective and efficient leadership, millennial women leaders therefore, should exert extra effort to understand the culture of the organization and the people working in it.

Because of the complexity of millennials' way of thinking, interests, and communication 


\section{Macrothink}

Journal of Public Administration and Governance

ISSN 2161-7104

2019, Vol. 9, No. 2

orientations, their ability to lead and steer the organization towards progress is still subject to many opposing views as reflected on existing literatures (Gursoy et al, 2008; Alsop et al, 2009; Zemke et al, 2000). The related literatures provide an overview of the leadership and management styles of millennial women leaders in different countries and on how these dynamics are distinct from the other gender and generation (Bernarte et al., 2015).

This study tries to fill in the gap in knowledge about the millennial women's leadership by delving deeper into their leadership style, work relationships, and the effects of gender and generation in the exercise of their duties as managers. Also, the study will be a good addition to the existing literatures in the Philippines about millennial women leaders which, at this time, are very limited.

\subsection{Theoretical Framework}

The Intersectionality Theory, as introduced by legal scholar Kimberley Crenshaw, is a framework for understanding the ways that the multiple aspects of our identities intersect, influence one another and compound to create unique experiences (Cho et al., 2013). This concept is regularly used to describe the ways that societal privilege and oppression is complicated by the different parts of our identity that are marginalized or privileged in society.

The relationship between gender, generation, and leadership is shown on the Figure 1 below.

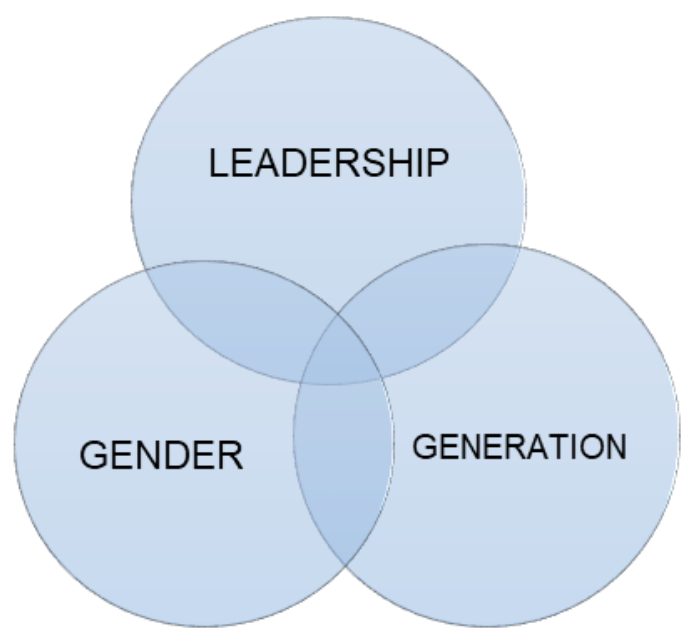

Figure 1. Intersectionality between Gender and Generation in Leadership

This research focuses on the intersectionality perspective in gender, generation, and leadership which is very relevant nowadays. Furthermore, it stresses the means as to how these factors relates to one another, as well as, its implication to the leadership of the millennial women based on their experiences.

\subsection{Blurring Gender}

While many areas of academic research are rather obscure, gender is something in which everyone has an opinion to (Kimmel, 2000). It indicates that more than research evidence, it is the personal experiences which are given emphasis and accepted as true. 
While stereotypes influence our behavior to a large extent, research has also evidenced a blurring of gendered traits. Cross-temporal meta-analyses on millennials have shown that millennial women are now more assertive than their female predecessors (Kelan, 2015). This is only an indicator of wider change in the appropriation of masculine and feminine values.

\subsection{Gender and Generation}

The topics of gender and generation are currently on the top of many corporate agendas. Millennials or people from the Generation Y have been popular topic in the general press. In the future time it is expected that $50 \%$ of the working population will be comprised of the millennial generation (PricewaterhouseCoopers (PwC), 2016). This makes it important for organizations to find out what makes this generation tick. Women are often seen as underused resource, too. In spite of decades of struggles and enacted legislations, many industries in the country remain male-oriented and male-dominated.

Very rarely are gender and generation considered together in providing answers to the questions of why millennials' views on work are different and why majority of women are not making it to the top of organizations. Nonetheless, there is some hope that a shift in purview is nearing in the next generation. The study of Pew Research Center (2010) found out for the first time that among young people ages 18 to 34, more young women (66\%) than young men $(59 \%)$ rated success in high paying career or professions that are important to their lives. A recent survey of millennials also revealed that women were just as likely to describe themselves as ambitious as men (Myers and Sadaghiani, 2010).

\subsection{Developing Millennial Women as Leaders}

Millennial women are confronted with the problem that there are few senior women available to act as role models. In addition, the content of these role models often seems to be not right. Authenticity is not only for millennials but particularly important for millennial women. It will also be important to stress that they can be whoever they want to be in the workplace but also to set realistic expectations on how that might look. It is a challenge for women to be perceived as authentic leaders due to masculine template of leadership.

Their young age and lesser experience as compared to their co-workers from the older generations indicates the need for millennial women acquire more experiential learning. It is a positive attribute of millennial women that they are open to criticisms and feedbacks because they can use this in transforming their behavior and improving their performance.

\subsection{Women Leadership}

For most of recorded history, women were largely excluded from formal leadership positions. Acquisition of which, is often a difficult task since women, in general, are faced with the problem of political imbalance in a male-oriented society (Gabriel, 2017). A comprehensive review of encyclopaedia entries published just after the turn of the last century identified only about 850 eminent women, famous or infamous, throughout the preceding two thousand years.

As Charlotte Bunche of the Women's Global Leadership Institute noted, over the last three 
decades, women have taken leadership role in redefining fundamental aspects of our lives including work, family, equality and justice. Nonetheless, the progress is but a piecemeal and women remain dramatically underrepresented in formal leadership positions (Rhode, 2003). Although women still go through more barriers prior to and while assuming leadership positions especially in areas that are male-dominated, they are given more opportunities to fare with the opposite gender because of today's legislations and policies favoring women and young professionals (Rice, 2007).

\section{Methodology}

The study attempts to understand how millennial women managers perform their leadership duties and how they overcome the gender typecasting in the workplace.

\subsection{Research Design}

Qualitative research is an umbrella term for a wide variety of approaches to and methods for the study of natural social life. The information or data collected and analyzed is primarily non quantitative in character, consisting of textual materials such as interview, transcripts, field notes and documents and/or visual materials such as artifacts, photographs, video recordings and Internet sites that document human experiences about others or one's self in social action or reflexive states (Saldana, 2011).

With the use of qualitative method, the study intends to understand the standpoint of millennial women leaders about leadership and all the struggles and challenges in the workplace. In the modern era of organization where the basis for managerial positions are not gender and age but merits, millennial women leaders continue to take lead, the study will take on the research of University of Texas where they said that women's leadership in the world of millennials rides on the success wheels of authenticity, and communicating the vision and values. Leadership lives at the intersection of the spark and values. Thus, this study aims to validate the millennial women managers' view on leadership and their approaches toward the conflicts and struggles in the workplace.

\subsection{Participant Selection and Study Locale}

Certain criteria were set to select the participants for this research including gender, age and position. Purposive sampling was used in the study. Participants should also meet the following criteria:

- Woman

- Filipino Millennials (born from 1981-1996)

- Holding a permanent position

- Presently holding a supervisory/managerial position

Looking into the criteria of the participants, Dr. Paulino J Garcia Memorial Research and Medical Center (DR. PJGMRMC), a tertiary, Level IV government hospital with 400 bed capacity located in Cabanatuan City, Philippines was the setting of the study. Four millennial 
women managers from the four different divisions of the hospital were chosen: one from Nursing, one from Hospital Operation Patient Support Services, one from Finance and one from Medical.

Dr. PJGMRMC which presently has 1,200 employees was the chosen setting of the study. The institution is adapting to the merit-based promotions, therefore the predominance of millennial women leadership is present. It was chosen as the setting of the study for its accessibility and for the availability of qualified participants who can provide appropriate information related to the subject of inquiry.

\subsection{Data Collection}

Interviews were conducted with the millennial women managers in which they were asked about how they came up with their present position; what are their views regarding the management of staff; what are their experiences in handling conflicts in the workplace and in building rapport with the staff; and lastly, how they defy the gender stereotyping in their work place to be able to achieve the organizational goals. Interviews were done one-on-one with the use of open- ended questions. Confidentiality of the participants' personal information was observed therefore the presentation of their data was general.

Participant Observation as defined by the Social Research Methods is one of the most common methods of qualitative data collection. It is a research technique in anthropology and sociology characterized by the effort of an investigator to gain entrance into and social acceptance by a foreign culture or alien group to attain a comprehensive understanding of the internal structure of the society.

This research also includes participant observation to directly study how millennial women leaders are in their workplace, how they interact with their subordinates and how they get things done. It also allows an in- depth and detailed understanding of the situation that nonparticipant observations cannot provide. Observation was made every Tuesdays and Thursdays and as needed, for the researcher to gather the enough detailed information to completely understand the data that can respond to the problems that were stated.

\subsection{Data Confidentiality}

Informed Consent from the participants was asked prior to the data gathering process. Confidentiality and anonymity were guaranteed as some part of the methodology would divulge a depiction of the personal accounts of their work that will lead to their identification. Furthermore, their real names will not be revealed as the researcher used an Alias for every participant. All the data and information gathered were used for research purposes only.

\section{Results and Discussion}

This research explored the leadership style of millennial women managers, how do they defy gender stereotyping in their workplace, and how do they build rapport with their subordinates and get the task done. Each topic that surfaced is presented and supported by the actual data gathered. Every topic defined was based on existing literatures. 


\subsection{Gender Stereotyping}

A study showed that young women had experiences of things which could be seen as reflecting gender inequality such as the difficulty in gaining respect, lack of female managers, and earning less than male colleagues (Scharff, 2011). Young women confronted gender inequality and put their focus away from the gender issue. They also accepted their age and lack of experiences as reasons to further improve themselves. In addition, young women stressed that individuals are distinct from one another; therefore, should not be always categorized and referred to solely on the basis of physiology and not on their innate and acquired capabilities. This reflects the theory of individualization which states that social conventions no longer bind individuals into their traditional roles and it is instead the role of the individual to succeed. Instead of seeing gender as an influential factor in their experience, young women see themselves as agents who chose do to certain things while ignoring others (Kelan, 2012).

\subsection{Millennial Women Leadership Styles}

The next generation of women leaders, Generation Y, has grown up in a context characterized by significant economic turbulence; the boom and bust, significant labor force shake ups, corporate greed scandals. Millennial women leaders experienced substantially different family milieu and workplace environment than the leaders in the past decades.

As far as the next generation of leaders, millennials, women and men are concerned, turbulence, according to Klenke (2017) is manifested in creative disruption and is a mark of their leadership styles.

In the interview, participants were asked about their description of a good leader. Their responses were 'understanding', 'reliable', 'willing to accept criticisms', 'open to suggestions', 'can work under pressure, 'great problem solver' and 'great motivator'. Though all of them admittedly said that their definition of an ideal leadership were way far from their perception of their own leadership.

As these young women leaders assume their supervisory and managerial positions, everyday seems to be a learning process, as they are still discerning the ways of making things work towards achieving the institutional goals and objectives.

Being young and being a woman also mean being perceived as weak and incompetent. It is an everyday struggle that confronts each of them and something which they continuously defies. It has been observed that the major factors of their approach to leadership revolve more on dealing with other people or on the relationship they have with their subordinates.

\subsection{Overcoming Gender and Age Stereotypes}

In an interview with Abi, who is works for the institution for four years and holds a supervisory position for two years, there are lots of instances that she feels intimated being called "Boss" by her subordinates who coincidentally were her college classmates who are older than her. Gaining their respect and imposing authority were the first challenges in her leadership. Based on the researcher's observation, though they can talk casually and joke 
around, the line that separates their friendship and working relationship is quite observable.

On the other hand, Annie, who upon her entry in has gotten the position, for she is the pioneer of her profession in the institution. It took few months before she had subordinates, majority who are males and some are older than her. In her case, it was an on the spot leadership, not having any previous experience of managing people she admittedly said that she feels her people think that she does not deserve the job but she is very persistent in learning every aspects of the job.

Ria, whose line of work are dominated by men, seem to manage and get along with her staff easily. She said that sharing the same interests make them easier to work and collaborate together; though in the beginning she had a hard time building rapport with her staff as she finds it hard to deal with aloof male co-workers. She told that part of her strategy was to "make them feel that they belong and all of their opinion matters".

Jane, who is the manager of their office, has subordinates who have work experiences that are equitable to her age. She firmly believes in the cliché saying that "Age is just a number". It is evident that she is an assertive woman. She said that she worked hard for the position; she undertook different development programs for her career advancement. As witnessed by the researcher, she is very dedicated and hardworking, she even works during her break to meet a deadline. In her case, she said that "I should show them an efficient work ethic. I want to be a leader that is worth emulating, from there I can gain their respect".

\subsection{Task Delegation and Conflict Management}

Abi prepares an assignment sheet every morning, "Effective naman, minsan din kailangan mong mag step up or help kapag hindi na nila magawa ang ibang task para matapos kaagad" (It is effective, there are instances that you'll help to finish the task promptly) The assignment sheet was her strategy in delegating the task, oftentimes the reason of some misunderstandings in the office. "Feeling $n g$ is a kong staff, parang majority ng task na mabibigat ay sa kanya, my reason is siya ang next in rank sa akin so dapat alam niya lahat ng whereabouts ng trabaho". (One of my staff feels like that majority of the serious tasks were always given to her. My reason for that is because she is the next in rank).

When there are disagreements she said "Ako, I am very willing to listen, kasi aminado naman ako na, I still have a lot to learn. Yun lang talaga siguro ang importante kapag may mga conflicts, maging open 'yung communication niyo to meet halfway para magkaroon ng understanding". (I am very willing listen, I acknowledge the fact that I still have a lot to learn, maybe that is the only thing important when you have conflicts, you should have an open communication to meet halfway and have that understanding).

Annie has a hard time in delegating task, having subordinates that are older and more experienced. "Ang tingin kasi nila dahil mas matanda sila ay mas alam nila ang lahat, pero hindi kasi sila tumitingin sa bigger picture $n g$ situation. Complain muna ang nauuna nang hindi pa naman nila nasusubukan." (Because they are older, they believe that they know better. Their complaints always come first, before even trying.) 
Ria seems to have no problems in task delegation "Swerte ako kasi parang sila yung mga kasama na alam na nila kung ano yung gagawin nila kapag pumasok sila" (I am very lucky because when my co- workers know there duty once they enter the workplace). She told me that there are very few instances that she has encountered conflicts "Siguro yun yung Pros kapag majority ng katrabaho mo ay mga lalaki, hindi sila masyadong demanding at mareklamo" (Maybe that's the advantage of having more male colleagues, they are not demanding and peevish).

Jane on the other hand, assures that tasks are well designated. "First thing na pagpasok, lagi ko sila ni reremind kung ano yung mga task nila for this day. We have our daily checklist, para lagi naming na momonitor ang individual at yung unit output. So far, effective naman. Goal oriented kami lahat dito, kaya there are just few instances na nagkakaproblema when it comes to task delegation". (Prior to starting our work, I always remind them what their tasks are for the day. We have our daily checklist so we can monitor the individual and office outputs. So far, this strategy is quite effective to us. We are all goal-oriented so there are just few instances that we have problems when it comes to task delegation).

When it comes to managing conflicts Jane has this to say. "May procedure naman kami in handling conflicts so yun lang sinusunod ko, kung meron. Pero I am grateful na bihira naman mangyari. Kung meron man kinakausap ko sila pareho to take their sides, from there nakakahanap naman agad ng resolution for them to meet halfway. Lagi ko na sinasabi na mahirap magtrabaho kapag may di kayo pagkakaintindihan. At kung personal issues man, huwag idadamay ang trabaho" (We have procedures in handling conflicts which I am following if there are any. But I am very grateful that it just happens occasionally. If there are conflicts, I talk to the two involved parties separately to hear their sides).

\subsection{Building a Good Working Relationship}

Abi, since time immemorial knew some of her workmates since they were her classmates. She has built that rapport with them. Some of her subordinates call her on a first name basis. "Hindi naman big deal sa akin yun. As long as nagagawa nila yung assigned task nila, walang problema". (It is a no big deal for me. As long as they are able to accomplish the assigned tasks there will be no problem).

"I personally believe we have good working and personal relationship with them. I am proud to say that we can accomplish every task that we have to do, because we have that certain understanding of our goals".

From the researcher's point of view, she is the type of leader, who is very laid back and she makes it appoint to have that good positive relationship with her subordinates without forfeiting what they need to.

Conversely, Annie has still to figure out how to handle people. Admittedly, she says " $\mathrm{Sa}$ ngayon, nasa proseso pa din kami na kinikilala namin ang isa't-isa when it comes to our work practices. I am very willing to listen sa mga inputs nila, and I try to explain my side din so kahit papaano, we can meet half way and do the best for our clients" (Right now, we are still on the process of getting to know each other when it comes to our work practices. I am 
very willing to listen in their inputs, and I try to explain my side so we can meet half ways and do the best for our clients).

Ria, on the other hand, when asked about her working relationship with her workmates cannot single out any misunderstanding that they had. "Parang pamilya ang turingan namin. Kaya ako araw-araw excited na pumasok, kasi alam ko na magkakasama kami sa lahat ng mga bagay" (We treat each other like a family. I am excited to go to work every day because I know that we are together in everything that we do.").

Though she may seem to be very tough, Jane has very good interpersonal skills. From the researcher's observation, she is very thoughtful when it comes to her people. She goes beyond what she's expected to do. "Simple things matter. Yung tipong tatanungin mo sila kung kumusta yung araw nila, may na encounter ba silang problema. Iba- iba kasi sila ng area, so within a day once lang nagkikita. Sabi ko naman na ako one call away lang if they have any concerns. It's a way na maramdaman nila na magkakasama kami dito." (Simple things matter. Like asking them how was their day, if they encountered problems. They have different areas of assignment so we only see each other once a day. I always emphasize that I am just one call away if they have any concerns. It is a way of making them feel that we are all in this together.)

\section{Conclusions and Recommendations}

\subsection{Conclusion}

Millennial women are the most educated group of women in history. They desire and continue to strive to eliminate the stigma that only men and older people are destined for leadership. A good, efficient and effective leader knows no age and gender.

The traditional notion of leadership based on a masculine hierarchical form of top-down leadership is now defied by the present situation where millennial women take the lead. They are will-driven and goal-getter.

Existing gender obstacles have challenged millennial women from growing in the workplace and their careers as they faced a culture that favored men and preconceptions about gender stereotypes. Millennial women have much to offer in the workplace as they continue to obtain higher education and make strides toward leadership positions. With their successes, these young women face great stresses and existential challenge as they confront old gender stereotypes, destroy barriers and advance their careers (Mallory, 2015).

The study identified the types of leadership millennial women of Dr. PJGMRMC have. They have different approaches in the every aspect of leadership that make them distinct from one another. They may have opposing views on leadership yet, they share a mutual aspiration of giving their best in getting their goals done.

In this present time of globalization, where the society is advocating equal opportunities for both men and women in leadership, large number of women are dominating the workforce. Women nowadays are gaining more freedom, obtaining higher level of education, and are becoming more self-determining. 


\subsection{Recommendations}

From the review of related literatures, discussion, and analysis of the respondents' answers, the following recommendations are arrived at:

1. Millennial women should use their modern-day skills to their advantage and to help co-workers from older generations who are struggling with the use of technological tools.

2. Millennial women should maximize their analytical and critical thinking skills in initiating change in the workplace.

3. The institution should organize orientations, coaching, and workshop sessions to help Millennial leaders further enhance their leadership and managerial skills.

4. The institution should encourage more collaborative activities between millennial leaders and older generations to solicit ideas fresh ideas from both tenured and new employees.

\section{References}

Alsop, R., Nicholson, P., \& Miller, J. (2009). Gen Y in the workforce commentary. Harvard Business Review, 87(2), 43-49.

Bernarte, R. P., Festijo, A. I., Layaban, M. D., \& Ortiz, S. U. (2015). Me, Myself and I: What Makes Filipino Millennials Narcissist? Asia Pacific Higher Education Research Journal (APHERJ) 2, no. 1. Retrieved from http://po.pnuresearchportal.org/ejournal/index.php/ apherj/ article/view/90

Cho, S., Crenshaw, K., \& McCall, L. (2013). Toward a Field of Intersectionality Studies: Theory, Applications, and Praxis. Signs, 38(4), 785-810. https://doi.org/10.1086/669608

Gabčanová, I. (2011). THE EMPLOYEES - THE MOST IMPORTANT ASSET IN THE ORGANIZATIONS. Human Resources Management, 1(12).

Gabriel, A. G. (2017). Indigenous women and the law: The consciousness of marginalized women in the Philippines. Asian Journal of Women's Studies, 23(2), 250-263. https://doi.org/10.1080/12259276.2017.1317705

Gursoy, D., Maier, T. A., \& Chi, C. G. (2008). Generational differences: An examination of work values and generational gaps in the hospitality workforce. International Journal of Hospitality Management, 27, 458-488. https://doi.org/10.1016/j.ijhm.2007.11.002

Kelan, E. (2012). Rising Stars: Developing Millennial Women as Leaders. Palgrave Macmillan. ISBN 978-0-230-29401-1

Kimmel, M. (2000). The Gendered Society. Oxford, UK: Oxford University Press.

Klenke, K. (2017). Women in Leadership: Contextual Dynamics and Boundaries, Second Edition - Google Books. https://doi.org/10.1108/9781787430631

Mallory, L. M. (2015). Factors That Motivate Millennial Public Servants in the Workplace. Walden University ScholarWorks. 
McDonald, P., \& Tang, Y. Y. (2014). Neuroscientific insights into management development: Theoretical propositions and practical implications. Group \& Organization Management, 39(5), 475-503. https://doi.org/10.1177/1059601114550712

Mertz, J. (2015). Activate Leadership: Aspen Truths to Empower Millennial Leaders.

Mlambo-Ngcuka, P. (2016). Together We Can Begin to Bend the Curve down, Speech by Phumzile Mlambo-Ngcuka, Executive Director of UN Women, at the UN commemoration of the International Day for the Elimination of Violence against Women, November 21, 2016. https://doi.org/10.4324/9781315270777-10

Myers, K. K., \& Sadaghiani, K. (2010). Millennials in the Workplace: A Communication Perspective on Millennials' Organizational Relationships and Performance. Journal of Business and Psychology, 25(2), 225-38. https://doi.org/10.1007/s10869-010-9172-7

Pew Research Center (2010). Millennials, Confident. Connected. Open to Change. Available at www.pewresearch.org/millennials.

Phelan, S. E., \& Lin, Z. (2000). Promotion Systems And Organizational Performance: A Contingency Model. Retrieved from https://www.researchgate.net/publication/2420318

Philippine Statistics Authority (2016). Census of population 2016.

PricewaterhouseCoopers (PwC) (2016). "Millennials at Work"; PwC's 14th Annual Global CEO Survey 2016. Oxford English Dictionary 2016 Edition.

Promotion_Systems_And_Organizational_Performance_A_Contingency_Model.

Rhode, D. (2003). The Difference "difference" Makes: Women and Leadership.

Rice, J. (2007). Women and Leadership: Transforming Visions and Diverse Voices.

Saldana, J. (2011). Fundamentals of Qualitative Research $3^{\text {rd }}$ edition.

Sandberg, S. (2013). Lean In: Women, Work, and the Will to Lead.

Scharff, C. (2011). It Is a Colour Thing and a Status Thing, Rather than a Gender Thing': Negotiating Difference in Talk about Feminism”. https://doi.org/10.1177/0959353511419816

Thomson, T. M. (1998). Management By Objectives; The Pfeiffer Library Volume 20, 2nd Edition.

Venter, E. (2017). Bridging the communication gap between Generation Y and the Baby Boomer generation, International Journal of Adolescence and Youth, 22(4), 497-507. https://doi.org/10.1080/02673843.2016.1267022

Yukl, G. A. (1998). Leadership in organizations. Pearson Education India.

Zemke, R., Raines, C., \& Filipezak, B. (2000). Generations at work: Managing the clash of veterans, Boomers, Xers, and Nexers in your workplace. Ney York: AMACOM American Management Association. 


\section{Copyright Disclaimer}

Copyright for this article is retained by the author(s), with first publication rights granted to the journal.

This is an open-access article distributed under the terms and conditions of the Creative Commons Attribution license (http://creativecommons.org/licenses/by/4.0/). 